Vol. 3, No. 4, December 2021, pp. 491-502,doi.org:10.52567/pjsr.v3i4.311

www.pjsr.com.pk

\title{
AN INVESTIGATION INTO RELATIONSHIP BETWEEN STUDENTS' ATTITUDE AND ANXIETY TOWARDS RESEARCH AND THEIR RESEARCH SELF-EFFICACY AT A LOCAL UNIVERSITY IN GILGIT-BALTISTAN, PAKISTAN
}

\author{
Dil Angaiz \\ Assistant Professor, Department of Educational Development \\ Karakoram International University, Gilgit-Baltistan, Pakistan \\ dilangaiz@kiu.edu.pk \\ Salma Jan \\ Visiting Lecturer, Department of Educational Development \\ Karakoram International University, Gilgit-Baltistan, Pakistan \\ salma_jan49@yahoo.com \\ Zahra Jabeen \\ Assistant Professor, Department of Educational Development \\ Karakoram International University, Gilgit-Baltistan, Pakistan \\ zahra.jabeen@kiu.edu.pk
}

\begin{abstract}
This study aimed to explore relationship between students' attitudes and anxiety towards research, and their research self-efficacy at a local university in Gilgit city. A sample of 102 students of a teacher education department responded to a 30-items written questionnaire. Results indicated more than 50\% students showed positive attitudes and high research self-efficacy towards research. Whereas less than $50 \%$ students showed anxiety towards research. It was found that in the programs where research is mandatory students showed higher positive attitude towards research, higher self-efficacy towards research and higher anxiety towards research than the programs in which doing research is optional. Results further indicated a positive strong correlation between students' attitudes towards research and their research self-efficacy. A positive weak correlation was found between attitudes towards research and anxiety towards research. On the contrary an inverse weak correlation was found between students' anxiety towards research and their research self-efficacy. Future researchers can conduct similar studies taking a reasonable large sample on anxiety towards research and research self-efficacy.
\end{abstract}

Keywords: self-efficacy, attitude towards research, anxiety towards research, university, relationship

\section{INTRODUCTION}

Research elements are considered very significant for the students in terms of the success or completion of their degree (Tella \& Adeyinka, 2014). Three factors considered to be important for success or failure in research are attitude towards research, anxiety towards research, and research self-efficacy. One of the three key factors seen to impact on research success in the literature is attitude towards research (Singh \& Chaudhary, 2015). Attitude towards research fundamentally means a comprehensive study of thinking, belief, actions, and the person's performance towards research (Shaukat, Siddiquah, Abiodullah, \& Akbar, 2014). However, students usually think that research is difficult to conduct, and it is complex to study (Adam \& Holcomb, 1986). Attitudes are supposed to persuade the performance of a student. So, to shaping the attitudes of students towards research is necessary (Li, 2012). Positive or negative attitude affect student's interest towards a particular subject (Zan \& Martino, 2007). Research studies such as (Angaiz, Jan, \& Mehmood, 2021; Onwuegbuzie \& Wilson, 2001) highlighted the significance of research skills for every degree program. However, some research studies (Natividad, Mangulabnan, \& Canlas, 
Angaiz, Jan, \& Jabeen

2019) discovered that students show negative attitude towards research with feelings of anxiety and tension even many students don't know about research methods at all.

Fear and anxiety are considered as the reasons of students failing to complete their dissertation or thesis. In a research study conducted by Oguan, Bernal, and Pinca (2014) found a strong positive correlation between high academic achievements and low anxiety towards research. Oguan et al., (2014) further described those problems such as, the difficulty of research, extra work given to the students and, students' nervousness towards the subject or research contributes towards anxiety of the students. According to them, usually students who feel research difficult and challenging have higher research anxiety. Therefore, they cannot perform well in the research courses. Likewise, McGrath (2002) considers fear and anxiety as the main reasons for students failing to complete their thesis and many students face huge anxiety towards the research process (Rezaei \& Zamani, 2013).

Nevertheless, researchers' beliefs on their own capabilities that motivate and inspire them to start a study in the first place is considered to be an important factor (Angaiz, 2015; Angaiz, Jan, \& Mehmood, 2021; Vaccaro, 2009) which according to Bandura (1994) is self-efficacy. For Bandura, self-efficacy is an individual's thinking about their potentials to generate selected levels of act that implement control over actions that influence their lives. Hence, research self-efficacy is self-belief of a person in his capabilities to successfully carry out the research tasks. Li (2012) described that in many studies it's shown that low self-efficacy effects negatively on the students' willingness to conduct research. They enter into research methodology with stress and anxiety while the high self-efficacy towards research is a key to success in the research methodology.

\section{Statement of the Problem}

Research is considered very important in higher educational institutions across the globe and research skills are very important for every degree program but many studies (Murtonen \& Lehtiner, 2003; Wilson, 2001 as cited in Papanastasiou, 2006) discovered that students show negative attitude towards research with feelings of anxiety and tension even many students don't know about research methods at all. Many students usually think that research is difficult to conduct, and it is complex to study (Adam \& Holcomb, 1986). Oguan et al., (2014) believed that there were some problems related to anxiety of the students towards research. These problems are related to the difficulty of research, workloads given to the students and, their nervousness towards the subject or research. Usually, the students who feel research difficult and challenging have higher research anxiety, and low research self-efficacy. Therefore, they cannot perform well in the research courses. Moreover, research is considered very important for the achievement and the fulfillment of any program they are enrolled in (Shaukat et al., 2014). Many research studies are done in the western countries on students' attitude and anxiety towards research, and their research self-efficacy (Bundura, 1994; Hebert, Kulkin, \& Ahn, 2014; Oguan et al., 2014; Singh \& Choudhary, 2015). In Pakistan, there have been done limited studies on the anxiety and attitude of students towards research (Butt \& Shams, 2013; Iqbal, 2011; Saleem Farid, \& Akhter, 2014; Shaukat et al., 2014). Iqbal (2011) conducted a research study on prospective teachers from different degree programs to investigate research attitude of students in Pakistan. He pointed out that there is urgent need of doing research in this topic. Similarly, there is lack of empirical research studies in the context of Gilgit-Baltistan, Pakistan on research and factors that enhance or hinder research culture in educational institutions (Angaiz, Jan, \& Mehmood, 2021). Since many previous studies related attitude towards research with anxiety and self-efficacy so this study attempted to explore the relationship between students' attitude and anxiety towards research and their research self-efficacy. Hence, this research study sets out to investigate the combined relationship between these three variables.

\section{Purpose of the Study}

The purpose of this study was to explore the relationship between students' attitudes and anxiety towards research and their research self-efficacy in a teacher education department at a public sector university in Gilgit-Baltistan, Pakistan. The exploration further included exploring students' level of attitude and anxiety towards research, and their research self-efficacy.

\section{Research Questions}

The following two questions guided the research study: 
- How do students of the teacher education department describe their attitudes and anxiety towards research, and their research self-efficacy?

- What relationships exist between students' attitudes towards research, their anxiety towards research, and their research self-efficacy?

\section{Significance of the Study}

This study would contribute to the sample teacher education department in several ways. For instance, the findings will set the base for teacher education programs to address issues related to student's anxiety towards research through research specific trainings for the students, designing mentoring programs for students, and helping students in related services from the department. Moreover, the department can take measures to boost and encourage student's research self-efficacy through developing specific trainings to the students through experts in the said field. Based on the findings of this study, teacher education departments can work on mechanisms to develop students' research self-efficacy. This would help the particular department to overcome students' anxiety towards research.

\section{REVIEW OF LITERATURE}

Attitude towards research refers to thinking, beliefs, feelings, ideas, and the behavior of an individual towards research (Saleem, Butt, \& Farooqi, 2014). Panastasiou (2005) defines attitude towards research as a multidimensional construct consisting of the degree to which students view research as useful for their career, as being of significance to their life in general. The students' attitudes towards any task or situation are formed due to their experiences with the family and friends, the educational environment, childhood concepts and attitudes, the media, school and community they live with (Bhaskar \& Soundiraraj, 2013). According to Krech and Crutchfield (1984), and Writig (2001), attitudes usually consist of three related components: the cognitive component, the emotional component and behavioral component. The cognitive component includes the individual's beliefs, thoughts or perceptions and information about some subject or situation. Whereas the emotional component includes the individual's feelings and emotions about a particular subject or situation, and behavioral component is related to an individual's readiness to carry out acts and certain responses that are consistent with their attitudes. According to Hammad (2016), the individual's attitudes towards a subject or a situation can be understood through the incentives, or the pros provided by that subject or situation to that person. Panastasiou (2005) claimed that the attitude can persuade the willingness of a student to learn a specific subject e.g. research. For instance, the positive attitude of students will boost up their intrinsic enthusiasm to do research and negative attitudes slow down the work in research. Student's attitudes effects how they mentally approach research including all the efforts connected to the research (Rezaei et al., 2013).

In many of the research studies conducted by various researchers (Hammad, 2016; Hussain, Shahid, \& Zaman, 2011; Liu \& Chen, 2013; Papanastasiou, 2005; Sagir, 2012) have related attitude of students towards research with stress and anxiety. Research anxiety involves feelings of nervousness, anxiety, and fear that students will not be able to do research. Fear and anxiety are often the reasons of students failing to complete their thesis and some students face huge anxiety towards the research process. It is common that students perform poorly when they experience pressure with their tasks and when they experience high level of anxiety during their studies. According to Guerrero (1990), anxiety sources can be understood through differences in age level, social class, complexity of tasks, greater familiarity and gender. In this regard, Czapinski and Peters (1991) claims that anxiety occurs due to the lack of certainty and knowledge of the events and the past experiences. There are two dimensions of anxiety i.e., physiological arousal and cognitive anxiety. Ingugiro (1999) and Robb (2005) claimed that the cognitive anxiety is the component that strongly affects performance. Likewise, Fazey, and Hardy (1988) stated that cognitive anxiety has a positive relationship with performance when physiological arousal is low.

In a research study conducted by Papanastasiou and Zembylas (2005), it was found that the main factors that contributed to the increase in students' anxiety in a research methods course were those of (a) the amount of work required, (b) the amount of material covered, (c) test taking, and (d) difficulty of the material covered in class, and (e) preparing individual research projects. Likewise, some researchers found that high academic achievement decrease the level of students' anxiety towards research and vice 
versa. For example, Oguan, Bernal, and Pinca (2014) conducted research and discovered in their study that the students who have high academic achievement have the low anxiety towards research and the students who have low academic achievement have high anxiety towards research. On the other hand, students who are medium achievers in their academic achievements are discovered research stressful but unexpectedly it shows that they don't feel the subject too complicated. Other researchers' (Wilson, 1998; Wilson \& Onwuegbuzie, 2001) found that students of undergraduate have higher level of anxiety towards research as compared to the graduate students. The study suggests that the undergraduate needs motivation and proper guidance to reduce their anxiety towards research. Hence, they should be given research projects and research based activities and let them to learn by their own experiences. Griffin (1991) explained that students who have high confidence to do research task are less likely to react in a negative way towards the research process. They have less fear for the research process and more likely to show greater importance on the study. On the contrary, in many cases, students feel research more difficult, and they find it difficult to learn. For instance, Khan, Shah, Farid, Gul, and Shams (2016) conducted a study on the worries of M.Ed. students towards research in private universities of Khyber Pakhtoon Khawa (KPK), Pakistan and found that very few students have positive attitude towards research and were willing to conduct research. Majority of the students were interested to study subjects instead of conducting research. Likewise, Zan and Martino (2007) in their research study found that postgraduate students' attitude towards research was better as compared to the undergraduate students. The reason may be that undergraduate students think research as a tough and difficult course and want to avoid this course. Conversely, it is possible that they assumed research in negative manner because they had to face several obstacles and could not understand the concepts of the research. Similarly, Shaukat et al. (2014) in their research study in Pakistan found that the participant students' of M.Phil/MS have more positive attitude as compared to the B.S (Hons.) and M.A students. The participant students of Ph.D. have significantly shown better attitudes than the students of M.Phil/M.S and B.S (Hons.) and M.A students. It can be assumed that the difference is due to lack of knowledge about research and its importance.

In the academic sphere, research also has a strong relation between different dimensions of selfefficacy. In academics, self-efficacy is the belief of an individual about his or her capability to do successfully the given tasks (Hebert et al., 2014). According to Bandura (1994), self-efficacy changes the way people feel, believe, think and motivate. People with high self-efficacy perform hard tasks with strong dedication and commitment. They enhance and maintain their hard work in the face of failure. They rapidly improve their sense of efficacy after failures or delays. They approach frightening positions with guarantee that they be able to work out control over them. Such an effective point of view constructs individual activities, decreases stress, and lowers weakness to depression. As a result, they develop high level of self -efficacy. The high level of self-efficacy increases the feeling of success, independence and the motivation to increase the success. When pupil has high self-efficacy, they feel confident, and they feel that they can get good grades in their academics, so the higher level of learning occurs. However, low level of self-efficacy decreases the success. In terms of research self-efficacy, it is the belief of a student about herself that how confident he or she is in doing a research.

Some researchers described that low research self-efficacy contributes towards negative attitude towards research with increased level of research anxiety. For instance, Li (2012) conducted a study and found in his study that the students who have high self-efficacy towards research methods, show higher effort towards their studies. On the other hand, the students who show low self-efficacy towards research, they can't show better attitude towards research, and they get low grades in their studies. Tella and Adeyinka (2014) stated that the low research self-efficacy of students is a major reason of student's negative attitude or anxiety towards research. Likewise, Students enter to the research work with the feeling of nervousness and stress. Li (2012) described that in many studies it's shown that low selfefficacy effects negatively on the students' willingness to conduct a research. They enter into research methodology with stress and anxiety while the high self-efficacy towards research is a key to success in the research methodology. Vaccaro (2009) suggested that people with higher levels of self-efficacy tend to chase challenging goals and to have strong dedication even when they face difficulties and problems. On the contrary, people with low self-efficacy are more likely to avoid the difficult and complicated tasks, 
have less dedication and effort to pursue their personal goals, and are more defenseless to stress and anxiety.

Research suggested strong correlation between research self-efficacy and attitude towards research. The higher the research self-efficacy, the higher the positive attitude towards research was expected (Li, 2012). Rezaei et al. (2013) conducted qualitative research on relationship between research self-efficacy, research anxiety, and attitude towards research and found that there is a negative correlation between research self-efficacy and research anxiety. On the contrary, they found positive correlation between research self-efficacy and attitude. The students who have positive attitude towards research were more confident to do research. Moreover, the students of $\mathrm{Ph} . \mathrm{D}$ show higher research self-efficacy as compared to the M.Phil students. This means that the Ph.D students have more positive attitude and they are more interested in conducting research. Ph.D students have higher self-efficacy because they have more experience and they have done more research related tasks. Similarly, Tella et al. (2014) conducted a quantitative research and it was found that there was significant relationship between the attitude towards research and research self-efficacy, research anxiety and attitude towards research. The results indicated highest correlation between research self-efficacy and attitude towards research. Moreover, there were weak correlation between students' anxiety towards research and attitude towards research.

\section{RESEARCH METHODS}

\section{Sample}

The sample comprised of 102 students from a total population of 211 students studied in B.Ed. Hons., MA Education, and MPhil Education program in the teacher education department of a public sector university in Gilgit-Baltistan. Thus, it represented $48.34 \%$ of the total population. At the time of data collection, all students present in the Department of Education took part in the survey from three programs of study (M.Phil in education, Masters in education, and B.Ed. Hons. Elementary in Education). Details about the sample is presented in table 1.

Table No. 1 Sampling

\begin{tabular}{llll}
\hline Program & Research participants & Total number of students & $\%$ \\
\hline M.Phil & 5 & 7 & $71.4 \%$ \\
M.A Education & 35 & 107 & $33 \%$ \\
B.Ed.(Hons. Elementary) & 62 & 97 & $64 \%$ \\
Total & 102 & 211 & $48 \%$ \\
\hline
\end{tabular}

\section{Research Instrument}

For this study, the constructs measuring students' attitude towards research was mostly adapted from Attitudes toward Research (ATR) scale which is developed by Papanastasiou (2005). Only ten items most suited to this research study were adapted from ATR. Similarly, the construct measuring student anxiety towards research was mostly adapted from ATR developed by Papanastasiou (2005). Likewise, the construct measuring students' research self-efficacy was mostly adapted from Rezaei et al. (2013) research self-efficacy scale. Only ten items most suited to this research study were adapted from Rezaei et al. (2013). The survey instrument consisted of four parts. Part A included items related to student attitude towards research, Part B related to their anxiety towards research, and Part C related to their research selfefficacy. Participants were instructed to rate their responses on a 7-point Likert scale. The respondents were asked to rate how important each of the attitude, anxiety, and self-efficacy items were in terms of their research, whereas, $1=$ Strongly Disagree; $2=$ Disagree; $3=$ Slightly Disagree; $4=$ Don't Know; $5=$ Slightly Agree; $6=$ Agree; and $7=$ Strongly Agree. Part D of the instrument asked the respondents to mention their demographic information regarding age range, program of study, gender, and their background (rural or urban).

Validity and Reliability

When an instrument measured what it was intended to measure, it was called validity (Angaiz, 2015). The content validity was determined through a jury of three professionals (university professors) associated 
with teacher education with a sound knowledge of teaching and research. The purpose of the research was informed, and the professors were asked to analyze the instrument for clarity, and relevance. Upon the jury's recommendation, the language of some of the items was simplified, repetitions were avoided, and some items were reworded for relevance and clarity. The Jury were given a scale from 1- 4, where 1 indicated less relevance and less clarity, and 4 indicated high relevancy and high clarity to consider against each item. This process helped to determine face validity of the instrument. The overall reliability of the tool was calculated using Cronbach's alpha which was 0.87 .

\section{Data Collection Procedure}

A consent letter was given to the concerned head of department to collect the data from three programs of study. After getting permission from the head of department, the researchers personally visited each program students in their classes and informed them about the purpose of research and seek their consent to collect data from them. A survey instrument consisted of 30-items (10 items in part A, 10 items in part $\mathrm{B}$, and 10 items in Part $\mathrm{C}$ ) with part $\mathrm{D}$ consisted of demographic information was administered to the research participants in person. Part A consisted of items related to attitude towards research, Part B about anxiety towards research, and Part $\mathrm{C}$ about their research self-efficacy. Part D consisted of the demographic variables of age, gender, background (rural or urban) and the programs they were enrolled. The survey questionnaire was coded from 1 to 102 to ensure their confidentiality. One hundred and two students from the Department of Educational Development from three programs (M.Phil, M.A Education, B.Ed. (Hons.) out of a total population of 211 student population participated in the survey.). The data were entered into the SPSS and saved it in a portable external drive.

\section{DATA ANALYSIS AND INTERPRETATION}

Data were analyzed under two research questions. Descriptive statistics were used to analyze question one. Whereas, Pearson Moment Correlation Co-efficient was used to measure correlation between students' attitudes towards research, their anxiety towards research, and their research self-efficacy. Results of descriptive statistics indicated that more than 50\% students showed positive attitude towards research, and research self-efficacy. Whereas, less than 50\% students showed anxiety towards research. Table 2 display the descriptive statistics for the variables of student attitudes towards research, their anxiety towards research, and their research self-efficacy. For the variable, attitude towards research the mean score of $(\mathrm{M}=56.30$; $\mathrm{SD}=10.68)$ with mean/number of items (5.63) indicated that participants attitudes toward research falls between slightly agree to agree on the Likert-Scale. Similarly, for the variable anxiety toward research a mean score of $(\mathrm{M}=43.58 ; \mathrm{SD}=11.89)$ with mean/number of items (4.36) indicated that participants' anxiety towards research falls between don't know to slightly agree on the Likert Scale. Likewise, for the variable research self-efficacy a mean score of $(\mathrm{M}=52.69 ; \mathrm{SD}=10.63)$ with mean/number of items (5.27) indicated that participants' research Self-efficacy falls between Slightly Agree to Agree on the Likert scale.

Table No. 2 Descriptive Statistics showing students' Attitudes towards Research, their Research Anxiety, and their Research Self-Efficacy

\begin{tabular}{lcccccc}
\hline & $N$ & Min & Max & $M$ & $\begin{array}{c}\text { M/\# of } \\
\text { Items }\end{array}$ & $S D$ \\
\hline $\begin{array}{l}\text { Attitudes Towards } \\
\text { Research }\end{array}$ & 102 & 10.00 & 70.00 & 56.30 & 5.63 & 10.68 \\
$\begin{array}{l}\text { Anxiety Towards } \\
\text { Research }\end{array}$ & 102 & 17.00 & 69.00 & 43.59 & 4.36 & 11.89 \\
Research Self-Efficacy & 102 & 15.00 & 70.00 & 52.69 & 5.27 & 10.63 \\
\hline
\end{tabular}

Moreover, the mean scores of research productivity items revealed that usefulness of research for their career' scored the highest mean $(M=6.21, S D=1.61)$ followed by 'research is very valuable' $(M=5.93 ; S D=1.65)$. Regarding anxiety toward research, students considered research complex $(M=5.07$, $S D=2.00)$ and complicated $(M=5.08 ; S D=1.89)$. Likewise, the highest self-efficacy was seen in students believe about themselves that they can do research $(M=5.81 ; S D=1.51)$. However, they show low research self-efficacy in the item "I believe I can do research with minimum support $(M=4.99 ; S D=1.98)$ and "I 
believe I am good in writing thesis. $(M=4.84 ; S D=1.55)$. This means that students need maximum support in research and that they need support in writing thesis as it shows low research self-efficacy. The following table shows a comparison between MPhil, MA Education, and B.Ed. Hons. Elementary program students regarding their attitude and anxiety towards research, and their research self-efficacy:

Table No. 3 Descriptive Statistics showing Programs of study with Students' Attitudes towards Research, their Anxiety towards Research, and their Research Self-Efficacy

\begin{tabular}{|c|c|c|c|c|c|c|}
\hline \multicolumn{2}{|c|}{ Program of study } & $N$ & Min & $\operatorname{Max}$ & $M$ & $S D$ \\
\hline \multirow{3}{*}{ M.Phil } & $\begin{array}{l}\text { Attitude Towards } \\
\text { Research }\end{array}$ & 5 & 62.00 & 68.00 & 64.80 & 2.95 \\
\hline & $\begin{array}{l}\text { Anxiety Towards } \\
\text { Research }\end{array}$ & 5 & 41.00 & 59.00 & 46.40 & 7.57 \\
\hline & Research Self-Efficacy & 5 & 50.00 & 55.00 & 53.20 & 1.92 \\
\hline \multirow{3}{*}{$\begin{array}{l}\text { M.A } \\
\text { Education }\end{array}$} & $\begin{array}{l}\text { Attitude Towards } \\
\text { Research }\end{array}$ & 35 & 10.00 & 67.00 & 52.17 & 12.30 \\
\hline & $\begin{array}{l}\text { Anxiety Towards } \\
\text { Research }\end{array}$ & 35 & 21.00 & 54.00 & 35.86 & 8.81 \\
\hline & Research Self-Efficacy & 35 & 15.00 & 68.00 & 50.14 & 11.94 \\
\hline \multirow{3}{*}{ B.Ed. } & $\begin{array}{l}\text { Attitude Towards } \\
\text { Research }\end{array}$ & 62 & 22.00 & 70.00 & 57.95 & 9.25 \\
\hline & $\begin{array}{l}\text { Anxiety Towards } \\
\text { Research }\end{array}$ & 62 & 10.00 & 62.00 & 39.39 & 11.58 \\
\hline & Research Self-Efficacy & 62 & 20.00 & 70.00 & 54.09 & 10.09 \\
\hline
\end{tabular}

Tables 3 indicates that students enrolled in B.Ed. Hons. Program has the highest research selfefficacy $(M=54.09, S D=10.09)$, followed by M.Phil program students $(M=53.20, S D=1.92)$. Whereas, MA Education program students have low research self-efficacy as compared to the other two program students $(M=50.14, S D=11.94)$.. There are two possibilities of students' high research selfefficacy in B.Ed. Hons., and M.Phil programs. The higher the number of years spent in the program, the higher the association could be with research related knowledge. As B.Ed. (Hons.) students remain in the institution for four years, whereas, M.A Education students remain for 2 years only. Secondly, it is mandatory for M.Phil and B.Ed. (Hons.) students to do research. Whereas, doing research is optional for Master's program students.

Similarly, the results indicated that students enrolled in M.Phil Program has the highest score in their anxiety towards research $(M=46.40, S D=7.57)$, followed by B.Ed. (Hons.) program students. $(M=$ $39.39, S D=11.85)$. Whereas, MA education program students show comparatively low anxiety towards research as compared to the other two program students $(M=35.86, S D=8.81)$. It can be inferred from these findings that M.Phil students show more anxiety towards research, as they are in the process of doing research. Whereas, B.Ed. (Hons.) program students have not started their research yet. On the contrary, Master's Program students have to opt for research or to take two courses.

Likewise, the results indicated that students enrolled in M.Phil Program has the highest score in their attitudes towards research $(M=68.00, S D=2.95)$, followed by B.Ed. program students. $(M=57.95$, $\mathrm{SD}=9.25)$. Whereas, M.A education program students have low scores in their attitude towards research as compared to the other two program students $(M=52.17, S D=12.30)$ respectively. These findings indicated that it is mandatory for M.Phil and B.Ed. (Hons.) program students to conduct research. So their attitudes are positive too. On the contrary, for Master's Program students, it's not mandatory to conduct research. So, they show comparatively low positive attitude towards research.

Moreover, in order to see the relationship between students attitude towards research, their anxiety towards research, and their research self-efficacy, Pearson Product Movement correlation analysis was done to determine strength and direction of relationship between the above mentioned variables. Cohen's (1988) as cited in Angaiz (2015) interpretations of the strength of relationships measured by Pearson Correlation Coefficients to indicate 0.10 as weak, 0.30 as moderate, and 0.50 as strong correlation were used to analyze relationship strength. Table 3 indicated the results of the correlation 
analysis for student attitudes towards research, their anxiety towards research, and their research selfefficacy.

Table No. 4 Correlation between Students' Attitudes towards Research, their Anxiety towards Research, and their Research Self-Efficacy

\author{
Attitude Towards Research Anxiety Towards Research
}

\begin{tabular}{llll}
\hline Anxiety Towards Research & $\mathrm{R}$ & .034 & \\
& $\mathrm{r}^{2}$ & $0.1 \%$ & \\
& $\mathrm{P}$ & .735 & \\
& $\mathrm{~N}$ & 102 & -.121 \\
& $\mathrm{R}$ & $.720^{* *}$ & $1.5 \%$ \\
Research Self-Efficacy & $\mathrm{r}^{2}$ & $51.84 \%$ & .227 \\
& $\mathrm{P}$ & .000 & 102 \\
\hline
\end{tabular}

Results pointed positive strong correlation between students attitudes towards research and their research self-efficacy $(r=0.720, p<0.05)$ with a shared variance of $51.48 \%$. A positive weak correlation was found between attitudes towards research and anxiety towards research $(r=0.034, p=0.735)$ with a shared variance of $0.1 \%$. On the contrary an inverse correlation was established between students anxiety towards research and their research self-efficacy $(r=-0.121, p=0.227)$ with a shared variance of $1.5 \%$ respectively.

\title{
DISCUSSION
}

In this study, we found that MPhil program students showed higher positive attitude towards research, followed by B.Ed. program students, than MA Education program students. Similarly, MPhil program students and B.Ed. program students showed comparatively higher anxiety towards research than MA Education program students. Likewise, B.Ed. program students and MPhil program students comparatively showed higher research self-efficacy than MA education program students. These findings showed an interesting picture regarding programs where research is mandatory students' attitude is high, anxiety is high, and self-efficacy is also high. In MPhil and B.Ed. Hons. Elementary, research is mandatory, whereas MA Education program students either have to opt for research thesis or study two courses in place of research. These findings are very much aligned with earlier research studies in which level of education and years spent in the university is a contributing factor regarding higher attitudes and anxiety towards research and higher self-efficacy towards research (Adeyinka, 2014; Li, 2012; Tella et al., 2014; Zan \& Martino, 2007).

This study found a strong positive correlation between attitude towards research and their research self-efficacy. These findings are supported by earlier research studies conducted in varying global contexts. Research suggested strong correlation between research self-efficacy and attitude towards research. The higher the research self-efficacy, the higher the positive attitude towards research was expected (Li, 2012). Rezaei et al., (2013) explained that students attitudes effects how they perceive research including all the efforts connected to the research. Positive attitude let the students to solve their own problems. On the other hand, negative attitudes slow down the work in research. The key element to develop positive attitude of students towards research is the influence of student's self-efficacy. Hill (2007) stated that a positive attitude plays vital role in the development towards the aims of a person. It means that attitude have control on the lives and manage that how to deal with persons and events. Oguan et al., (2014) found in their study that in general, the students who have good grades or they perform well in their academic career, they have shown positive attitude towards research although most of the students show negative attitude on difficulty of research. In many studies it was demonstrated that the students who show positive attitude, they have higher possibility to perform well academically. Panastasiou (2005) 
claimed that the attitude can persuade the willingness of a student to learn a specific subject e.g. research. Moreover, the positive attitude of a student will boost up his intrinsic enthusiasm to do research. Similarly, Li (2012) conducted a study and revealed in his study that the students who have high selfefficacy towards research methods, show higher effort towards their studies. Ultimately, they score good grades. It means that they have confidence on their self. And they think that they are able to do well. Similarly, Tella et al., (2014) conducted a quantitative research in two universities of Ilorin, Nigeria. The sample included 113 students from three departments. The results indicated highest correlation between research self-efficacy and attitude towards research. On the other hand, the students who show low selfefficacy towards research, they can't show better attitude towards research, and they get low grades in their studies. On the contrary, in the context of Pakistan, students' show negative attitudes towards research in one of its province of Khyber Pakhtoon Khawa (KPK) (Khan, Shah, Farid, Gul, \& Shams, 2016) reluctantly showed low self-efficacy towards research. Similarly, the research conducted by Rezaei et al. (2013) at Shiraz University, Iran, support these findings. They found positive correlation between research self-efficacy and attitude.

This study also found a weak positive correlation between attitudes towards research and anxiety towards research $(\mathrm{r}=0.034, \mathrm{p}=0.735)$. These findings are very much in association with the findings of Khan, Shah, Farid, Gul, and Shams, 2016. They found that very few students have positive attitude towards research and prepared to conduct research. Majority of students were interested to study subjects instead of conducting research. Students show anxiety towards research and reported that research is complicated for them, it is time consuming, research is a complex subject, and it is difficult to conduct a research. Further, students showed their anxiety whether they conduct a research or study subjects to for the completion of their degree. The students who have positive attitude towards research were more confidents to do research. Tella et al., (2014) in their research study conducted in two universities of Ilorin, Nigeria found a weak correlation between students' anxiety towards research and attitude towards research. Oguan, Bernal, and Pinca (2014)'s research on the students who have already taken the research course in the College of Arts and Science, found that students who have high academic achievement have the low anxiety towards research and the students who have low academic achievement have high anxiety towards research. On the other hand, the students who are medium achievers in their academic achievements are discovered research stressful but unexpectedly it shows that they don't feel the subject too complicated. It means academic achievement is a contributing factor for more or less anxiety towards research, which leads to either positive attitudes or negative attitudes towards research. Moreover, students level of study is also one of the contributing factor of their anxiety towards research. For instance, a number of researchers (Wilson, 1998; Wilson \&Onwuegbuzie, 2001) conducted a research in the Buckingham College, USA. They found that it is probable that the student of undergraduate have higher level of anxiety towards research as compared to the graduate students, due to two reasons. The first reason was that, because of the higher level of academic education, the anxiety of students reduced. Secondly, it is difficult for the undergraduate students to know the significance of the research especially when they are enrolled in such course in their studies. The study suggests that the undergraduate needs motivation and proper guidance to reduce their anxiety towards research. Hence, they should be given research projects and research based activities and let them to learn by their own experiences.

Finally, this research study also found an inverse weak correlation between students' anxiety towards research and their research self-efficacy $(r=-0.121, \mathrm{p}=0.227)$. These findings are also associated with earlier research studies conducted by different researchers. For example, Griffin (1991) explained that students who have high confidence to do research task are unlikely to react in a negative way towards the research process. They have less fear for the research process and more likely to show greater importance on the study. Likewise, Griffin (1991) explained that students who have high confidence to do research task are less likely to react in a negative way towards research process. They have less fear for the research process and more likely to show greater importance on the study. Oguan et al., (2014) believed that usually the students who feel research difficult and challenging have higher research anxiety. Therefore, they cannot perform well in the research courses. Li (2012) described that in many studies it's shown that low self-efficacy effects negatively on the student's willingness to conduct a 
research. They enter into research methodology with stress and anxiety while the high self-efficacy towards research is a key to success in the research methodology.

\section{RECOMMENDATIONS AND CONCLUSION}

The results of this study suggested several avenues in which Department of Education of the sample university specifically and generally the university can address student concerns related to research in order to overcome their anxiety, and to boost their research self-efficacy through inculcating positive attitudes towards research. We found that in the programs where research is mandatory, students showed higher anxiety towards research than MA education program where research is optional. Similarly, in both MPhil program and B.Ed. Hons. Elementary program in which research is mandatory, students' attitude and self-efficacy is higher than the program in which research is optional. It is highly recommended to the concerned department to overcome students' anxiety towards research through ongoing research sessions where students could speak up about the problems which causes anxiety in them. The teacher education department and faculty are recommended to offer more research courses and design research related classroom assignments, so, that students attitudes towards research could positively be enhanced, which will help them to enhance their research self-efficacy too in the programs where research is optional. This study was conducted in one department of teacher education. Future researchers can conduct this research taking a reasonable large sample across the universities in GilgitBaltistan. This study can't find the problems related to the anxiety of students towards research, which can further be investigated through qualitative aspect of research. Qualitative research will help the researcher to deepen understanding of unique characteristics that leads to the attitude, anxiety, and research self-efficacy of students.

\section{LIMITATIONS OF THE STUDY}

The study was limited to the existing students of teacher education department that limits the scope of research to only one department. Moreover, the study focused on the quantitative aspects of the research only and not the qualitative aspects. Hence, one of the delimitations of this research study is lack of in depth understanding about students attitudes towards research, their anxiety towards research, and their research self-efficacy. The comparisons made between the programs showed an uneven distribution of the sample, future researchers can take a homogenous research sample to better compare results.

\section{REFERENCES}

Adams, N. A., \& Holcomb, W. R. (1986). Analysis of the relationship between anxiety about mathematics and performance. Psychological Reports, 59 (1), 943-948.

Ajzen., Icek., \&Fishbein, M., (2000). "Attitudes and the Attitude-Behavior Relation: Reasoned and Automatic Processes.” In European Review of Social Psychology, 11 (1), 1-33.

Angaiz, D. (2015). An Investigation of Determinants of Teacher Education Faculty Research Productivity in Public Sector Universities of Pakistan. Doctoral Dissertation: Dowling College Long Island, New York.

Angaiz, D., Jan, S., \& Mehmood, S. (2021). Exploring the relationship between faculty Research Productivity and their Individual Characteristics. Perspectives on Humanities and Social Sciences, 02, 1-16.

Bandura, A. (1994). Self-efficacy. In V. S. Ramachandran (Ed.), Encyclopedia of human behavior. New York: Academic Press. Encyclopedia of mental health,4 (2),71-81.

Bhaskar, C., \& Soundiraraj, S. (2013). A Study on Change in the Attitude of Students towards English Language Learning. English Language Teaching, 6(5), 111-116.

Boostrom, R. J., Philip, W., \& Hansen, D. T. (1993). Coming together and staying apart: How a group of teachers and researchers sought to bridge the research practice gap. Teachers' College Record, 95(1), 35-44.

Butt, I. H., \& Shams, J. A. (2013). Master in Education Student Attitudes towards Research: A Comparison between two Public Sector Universities in Punjab. A Research Journal of South Asian Studies, 28(1), 97-105. 
Czapinski, J., \& Peters, G. (1991). The onion theory of happiness: Basic concepts and cross-cultural test. In N. Bleichrot \& P.D. Drenth (Eds.), Contemporary issues in cross-cultural psychology (pp. 196-216). Amsterdam: Swets \& Zeitlinger. Francisco, CA, April 18-22, 1995) .

Griffin, B. W. (1991). Graduate student self-efficacy and anxiety toward the dissertation process. Journal of Counseling Psychology, 48(1), 344-354.

Hemmings, B., \& Kay, R. (2009). Lecturer self-efficacy: Its related dimensions and the Influence of gender and qualifications. Issues in Educational Research, 19(3), 243-254.

Herbert, C., Kulkin, H. S., \& Ahn, B. (2014). Facilitating research self-efficacy through teaching strategies linked to self-efficacy theory. American International Journal of Social Science, 3(1), $44-50$.

Hill, N. (2007). Think and grow rich. Random House Publishing Group, 4 (2), 22-34.

Hussain, T., Chaudhary, A. Q., Akhter, M., Abid, N., \& Sabir, S. (2016). A Study on Attitude towards Research among Technology Education Students in Pakistan. Bulletin of Education and Research, 38 (2), 113-122.

Hussain, M., Shahid, S., \& Zaman, A. (2011). Anxiety and Attitude Of Secondary School Students Towards Foreign Language Learning. Social and Behavioral Sciences, 29, 583 - 590.

Iqbal, H. M. (2011). Prospective teacher's attitude towards research. Unpublished master's thesis, Institute of Education \& Research.

Kakupa, P. (2019). Students' Attitudes towards Research: A Study of Graduate Education Students at a Chinese Normal University. Educational Process: International Journal, 8(2), 97-110.

Khan, P. N., Nazish, K. S., Sumera, G., \& Shams, F. (2016). A Study of the Worries of Master Students (M.Ed.) Towards Researches in Private Sector Universities, KPK,Language in India. Retrieved from https://core.ac.uk/reader/357222704

Krech, D., \& Crutchfield, R. S. (1984). Theory and problems of social psychology. New York: McGraw-Hill

Lei, S. A. (2008). Factors changing attitudes of graduate school students toward an introductory research methodology course. Education, 128(4), 667-685.

Li, L. K.Y. (2012). A Study of the Attitude, Self-efficacy, Effort and Academic Achievement of CityU Students towards Research Methods and Statistics. Discovery - SS Student E-Journal, 1(1), 154183.

Liu, H., \& Chen, T. (2013). Foreign Language Anxiety in Young Learners: How It Relates to Multiple Intelligences, Learner Attitudes, and Perceived Competence. Journal of Language Teaching and Research, 5(4), 932-938.

Natividad, A. M., Mangulabnan, J., \& Canlas, J. R. (2019). Self-Efficacy, Anxiety Level, and Research Attitude of PreService Teachers. International Journal of Humanities and Social Sciences, 11(1), 1-9. https://doi.org/10.26803/ijhss.11.1.1 Dr. Alma M.

Oguan, F. E., Bernal, M. M., \& Pinca, M. C. D. (2014). Attitude and Anxiety towards Research, Its Influence on the Students' Achievement in the Course.Asian Journal of Management Sciences \&Education, 3(4) 1-15.

Onwuegbuzie, A. J., \& Wilson, V. A. (2003). Statistics anxiety: Nature, etiology, antecedents, effects, and treatments: A comprehensive review of the literature. Teaching in Higher Education, 8(6), 195209.

Ozan, E. C., \& Korkmaz, O. (2018). Students' Perceptions and Attitudes of Self -Efficacy Oriented by Research-Inquiry. Participatory Educational Research, 5(1), 31-42.

Papanastasiou, E. C. (2005). Factor structure of the attitudes toward research scale.Statistics Education Research Journal, 4(1), 16-26.

Papanastasiou, E.C. \& Zembylas, M. (2008). Anxiety in Undergraduate Research Methods Courses: Its Nature and Implications. International Journal of Research \& Method in Education. 31. 10.1080/17437270802124616. 
Rezaei, M., \& Zamani-Miandashti, N. (2013). The relationship between research self-efficacy, research anxiety and attitude toward research: A study of agricultural graduate students. Journal of Educational and Instructional Studies in the World, 3(4), 69-78.

Sagir, S. (2012). The Primary School Students' Attitude and Anxiety Towards Science. Journal of Baltic Science Educofion, 11(2), 127-140.

Saleem, K., Butt, I. H., \& Farooqi, M. T. K. (2014). Relationship between Students' Research Attitude and Program Fee in Higher Education Institutions of Pakistan. Journal of Research and Reflections in Education, 8(2), 139 -145.

Saleem, K., Farid, S., \& Akhter, N. (2015). Gender Differences in Research Attitudes: Comparison of Public and Privates Sector Postgraduate Students' Attitude towards Research. Pakistan Journal of Social Sciences (PJSS), 35(2), 2669-679.

Shaukat, S., Siddiquah, A., Abiodullah, M., \& Akbar, R.A. (2014). Postgraduate Students' Attitudes towards Research. Bulletin of Education and Research, 36(1), 111-122.

Shkedi, A. (1998). Teachers' attitudes towards research: A challenge for qualitative researchers. International Journal of Qualitative Studies in Education, 11(4), 559-577.

Singh, G., \& Choudhary, N. K. (2015). A Study of Attitude of M.Ed. Students towards Research.Indian Journal of Research, 4(4), 1-20.

Swindoll, C. R. (2012). Quotable quotes. Retrieved from http://www.goodreads.com/ quotes/267482-thelonger-i-live-the-more-i-realize-theimpact,retrived on 02-07-2016.

Tella \& Adeyinka. (2014). A Comparative Analysis of Self-Efficacy, Anxiety and Attitude towards Research of Undergraduates Enrolled in the Research Methodology Course, 18(1), 127-150.

Unrau, Y. A., \& Beck, A. R. (2005). Increasing research self-efficacy among students in professional academic programs. Innovative Higher Education, 28(3): 187-204.

Vaccaro, N. (2009). The relationship between research self-efficacy, perceptions of the Research training environment and interest in research in Counselor education doctoral students: an ex-post-facto, Cross-sectional correlation investigation.

Wajid, U., \& Jami, H. (2020). Research self-efficacy among students: Role of metacognitive awareness of reading strategies, research anxiety, and attitude towards research. Pakistan Journal of Psychological Research, 35(2), 271-293.

Westhuizen, S. V. (2014). Postgraduate students' attitudes towards research, research self-efficacy and knowledge of research in an online module. South African Journal of Higher Education 28(4):1414-1432

Witig, A. (2001). Introduction to psychology. (2.nd ed), New York, Mc Graw-hill.

Zan, R., \& Martino, P. D. (2007). Attitude toward mathematics: Overcoming the positive/negative dichotomy, TMME (The Montana Mathematics Enthusiast) Monograph.3(1), 157-168. 